\title{
Limits to adaptation to interacting global change risks among smallholder rice farmers in Northwest Costa Rica
}

Benjamin P. Warner ${ }^{1,2}$, Christopher Kuzdas ${ }^{1,3}$, Mariel G. Yglesias ${ }^{4}$, Daniel L. Childers ${ }^{1}$

${ }^{1}$ School of Sustainability

Arizona State University

Wrigley Hall

Tempe, AZ 85287

USA

${ }^{2}$ Department of Environmental Conservation

University of Massachusetts

Holdsworth Hall

Amherst, MA 01060

USA

${ }^{3}$ Environmental Decisions for Global Change

Centro Agronómico Tropical de Investigación y Enseñanza (CATIE)

Turrialba, Cartago

Costa Rica

${ }^{4}$ Ecological Program

Originative - Costa Rica

Costa Rica Office

Esparza, Puntarenas

Costa Rica

\section{Acknowledgements}

Funding was generously provided the C.W. \& Modene Neely Charitable Foundation, Organization for Tropical Studies National Science Foundation grants (\#s 0553925 and 1132840), and the GISER Integrative Society and Environment Research Program. Thanks are also extended to the farmers who gave their time to be involved in this research in the hope that it would inform sustainable development. Our gratitude is extended to Hallie Eakin and Joshua Abbott for extremely constructive comments on multiple drafts of the manuscript, and to Carolina Murcia for her vision and support of this research. Finally, we would like to thank the anonymous reviewers for their constructive comments. 


\title{
Limits to adaptation to interacting global change risks among smallholder rice farmers in Northwest Costa Rica
}

\section{Highlights}

We discuss theoretical links among risks, livelihood goals, and adaptation limits Identity and security delineate adaptation limits among surveyed rice farmers Farmers must adapt to water scarcity and decreased market access Adaptation to water scarcity produces vulnerability to decreased market access Farmers are trapped in a "catch-22" and forced to abandon livelihood goals

\begin{abstract}
In this paper, we discuss the theoretical relationships among interacting global change risks, valued livelihood goals, and adaptation limits. We build from research on the impacts of multiple and interacting global change risks in lesser-developed countries and seek to understand household adaptation limits in agrarian communities. We ask: What are valued livelihood goals among smallholder farmers in Northwest Costa Rica? How do socio-economic determinants of adaptive capacities determine their ability to meet these goals in the face of the impacts of interacting global change risks? Our data were based on focus groups, interviews, survey responses from 94 smallholder farmers, government statistics, and published literature. We analyzed our data using qualitative content analysis and quantitative logistic regression models. Our analysis showed that farmers perceived rice production as an identity, and that they were being forced to consider limits to their abilities to adapt to maintain that identity. We found that farm size, cattle ownership, years spent farming, and household income variety were determinants of their abilities to remain in rice production while maintaining sufficient levels of livelihood security. We also showed that for those households most vulnerable to water scarcity, their ability to successfully adapt to meet valued livelihood goals is diminished because adaptation to water scarcity increases vulnerability to decreased rice-market access. In this way, they become trapped by the inability to reduce their vulnerability to risks of the interaction between global changes and therefore abandon valued identities and livelihoods.
\end{abstract}

\section{Keywords}

Transformative adaptation; adaptation limits; valued livelihood goals; Costa Rica; interacting risks

\section{Introduction}

Multiple types of global change processes increasingly impact rural development programs; these include regional drought and changes in international crop markets and trade liberalization policies, among others. The interplay between these processes can impact rural livelihoods in unforeseen and surprising ways (Leichenko, et al., 2010; Leichenko \& O'Brien, 2008; O'Brien \& Leichenko, 2000). The study of climate change induced drought, or the study of impacts of global economic changes on rural livelihoods by themselves may not account for the dynamic interrelations and feedbacks between these global change processes. In order to promote the sustainability of rural development 
programs, we must begin to systemically address the impacts of these complex interactions on the valued goals of rural households. Global change scientists have studied how these complex interactions can transfer among spatial scales, and how they often increase the vulnerability of the rural poor (Turner et al., 2003). Here, we build on this research and address the complex interactions among global changes that interact to increase the vulnerability of the most vulnerable, which then force households to confront adaptation limits beyond which they may no longer meet valued livelihood goals.

Recent research and understanding about adaptation limits in rural areas provides a working framework to address the impacts of global changes on community-scale smallholder farm populations (Dow et al, 2013; Martin, et al., 2013; McDowell \& Hess, 2012). Research on the determinants of adaptive capacity has shown that the household socio-economic context often dictates differences in the outcomes of global change impacts at the community scale (Below et al., 2012). These contexts also produce the specific adaptation limits of households throughout lesser-developed countries (Dow et al., 2013). To date, much of this research has focused on the impacts of and adaptations to climate change, and more commonly climate change induced drought. However, smallholder farming communities often face multiple, interacting risks simultaneously, and the outcomes of the impacts of these risks vary among households (Morton, 2007).

In this research, we seek to understand how different adaptive capacities among smallholder farmers in Northwest Costa Rica determine their ability to continue meeting valued livelihood goals in the face of worsening impacts of interacting global change risks. Specifically we ask: What are valued livelihood goals among smallholder farmers in Northwest Costa Rica? How do socio-economic determinants of adaptive capacities determine their ability to meet these goals in the face of the impacts of interacting global change risks? The Arenal-Tempisque Irrigation Project (Proyecto de Riego ArenalTempisque, PRAT) in Guanacaste Province, NW Costa Rica, our case study site, has been heavily impacted by drought and trade liberalization (Warner, Kuzdas, \& Childers, 2015). These global changes have caused many smallholder farmers to confront adaptation limits and ultimately many have abandoned valued livelihood goals.

In this paper, we discuss the theoretical relationships among interacting global change risks, valued livelihood goals, and adaptation limits. Then, we describe our case study and data that include focus groups, household surveys, and interviews. We report the results of our analysis and discuss their significance in the context of the ArenalTempisque Irrigation Project and research on the human dimensions of global change.

\section{Theoretical framework and definitions}

Morton's (2007) ontological framework dictates that research on smallholder farm adaptations and vulnerabilities should (1) recognize the complexity and location of production systems and (2) incorporate both climate and non-climate stressors on rural livelihoods. We build from this framework and research that has considered how households adapt to the impacts of global change processes, which include changes in both the economy and the climate (Adger et al., 2009; Christoplos, 2010; Eakin et al., 
2009; Eakin, 2003, 2005; S. Eriksen \& Silva, 2009; Leichenko et al., 2010; Leichenko \& O’Brien, 2008; Adger, 1999; O'Brien \& Leichenko, 2000; O'Brien, et al., 2009). We conceptualize global change processes as impacting vulnerable households in different ways, resulting in determinate outcomes. Here, we define vulnerability as the degree to which a household may be impacted adversely by the outcomes, or the potential outcomes, of global change risks (Eriksen \& O'Brien, 2007; Eriksen et al., 2011). These outcomes depend on household exposure and sensitivity to an impact, and on whether and how households can and do adapt. Exposure represents the condition of being impacted (Leichenko \& O'Brien, 2008).

We define adaptations as responses to observed or expected global change risks - their effects and impacts - in order to alleviate adverse impacts of change or take advantage of new opportunities (Adger et al., 2005; IPCC, 2001) to meet valued goals (Füssel, 2007). These adaptations can be made either in anticipation of or following from exposure. Marshall \& Marshall (2007) show that adaptations are a function of the capacity of a household to change, and their perceptions of risks to livelihood goals. We distinguish coping mechanisms as specific to a type of household adaptation (UNDP, 2005), and we define them as adaptations that diminish the ability of a household to meet valued livelihood goals in the face of future impacts (Smit \& Wandel, 2006). Prolonged coping can reduce household capacity to adapt, and may force households beyond adaptation thresholds, beyond which they cannot meet valued livelihood goals (Jones, 2001; Roncoli et al., 2001).

Valued livelihood goals are critical to our conceptualization of adaptation and in turn, to defining adaptation limits. Household adaptations to global changes that result in a household's ability to better meet valued goals are considered successful within this context. These adaptations are a function of household capacities to pursue new opportunities and to reduce their sensitivity and exposure to the impacts of global change risks. These capacities are largely dependent on the underlying socio-economic context and the larger political economy that also define specific valued livelihood goals (Cohen et al,, 1998; Klein et al., 2007; Yohe et al., 2007). In this way, we liken valued livelihood goals to Alkire's (2002) dimensions of human development, and define them as "nonhierarchical, irreducible, incommensurable basic kinds of human ends." Valued livelihood goals do not "derive from nor divide up an idea about what a good life is, but rather are reasons for action." Nor are they static. Within different communities and contexts, goals necessarily take different forms. For example, while identity may be a basic human end (Max-Neef, 1993), Lerner, et al. (2013) found that the maize-producer identity among farmers in the Toluca Metropolitan Area, Mexico is a highly valued livelihood goal and therefore persists even through rapid urbanization pressures.

Adaptation limits represent thresholds beyond which households can no longer adapt or cope with the impacts of global change risks to meet valued livelihood goals. As risks associated with global changes increase, risks to livelihood goals may become intolerable, at which point households must either live with intolerable risk of losses, revise attitudes about what is a valued objective, or change behavior radically (i.e., transformative adaptation) to avoid the intolerable risk of loss (Dow et al., 2013). 
Intolerable risks are those that fundamentally threaten a valued livelihood goal despite adaptive actions to minimize the risks (Dow, Berkhout, \& Preston, 2013; Dow, Berkhout, Preston, et al., 2013). We rely on Adger et al.'s (2009) conceptualization of adaptation limits, and define them as constructed by the underlying socio-economic context, which includes ethics, knowledge, and attitudes toward risk. Limits to adaptation depend on valued livelihood goals. In this way, adaptation limits are refined by context and therefore malleable, but they are very real and experienced by households facing risks. At adaptation limits, individuals within households may perceive transformative adaptations as the necessary final response to escape the impacts of intolerable risks to livelihood goals. Transformative adaptations mark adaptation limits beyond which households cannot adapt to intolerable risks to meet existing valued livelihood goals (Dow et al., 2013). In certain socio-economic-ecological contexts, transformative adaptations may allow households to redefine valued livelihood goals and avoid long-term livelihood losses. In other contexts, few alternative livelihood options may be available to households and therefore transformative adaptations may result in loss of land tenure, poverty, and food insecurity.

For the most vulnerable in less-developed countries, household perceptions about the efficacy of adaptive capacities may be closely linked to their ability to avoid adaptation limits and devolve into long-term poverty, where few alternative livelihood options exist. Accordingly, the determinants of transformative adaptations that mark adaptation limits provide insights into household vulnerabilities that may be addressed in rural development programs to better allow households to meet valued livelihood goals in the face of global change risks. However, the same socio-economic determinants of successful adaptation to one risk may increase household vulnerability to another. This interplay between interacting global change risks, valued livelihood goals, and adaptation limits is not well understood in many rural development programs, but it is critical to their success.

\section{Research site and design}

\subsection{Research site}

Guanacaste Province in Northwest Costa Rica is a multi-faceted case that that is representative of many developing rural semi-arid regions (CIFOR, 2014; Kuzdas, Wiek, Warner, Vignola, \& Morataya, 2014). The Province also faces a number of interlinked rural development challenges including widespread poverty and food insecurity (Barten, Montiel, Espinoza, \& Morales, 2002). To address these challenges, the Costa Rican government initiated the Arenal-Tempisque Irrigation Project (Proyecto de Riego ArenalTempisque, PRAT) in 1983 . The PRAT provides up to $5,616,000 \mathrm{~m}^{3} /$ day of water to farmers in the Tempisque River Valley from Lake Arenal to the east (Figure 1). The PRAT is the largest irrigation system in Central America. More than 1000 farms benefit from the project, generating over 20,000 jobs ( 40\% are seasonal) and income of approximately US\$163 million annually (SENARA, 2013). A series of expansions between 1983 and 2006 have increased the PRAT's size to just over 28,000 hectares of irrigated land in 2014. Of that sum, approximately 5,300 hectares were purchased by the 
Agricultural Development Institute of Costa Rica (Instituto de Desarrollo Agrario, IDA) at different times, and then transferred, at minimal cost, over to poor families through agrarian reform initiatives aimed at lowering the province's stubbornly high poverty rate. These IDA-acquired parcels are shown in Figure 1. The remaining 22,700 hectares were brought under irrigation through a series of public-private agreements with large landholders requiring lands to be used "effectively" in exchange for subsidized water. Edelman (1992) and Warner et al. (2015) provide detailed descriptions of the development and current condition of these public-private agreements.

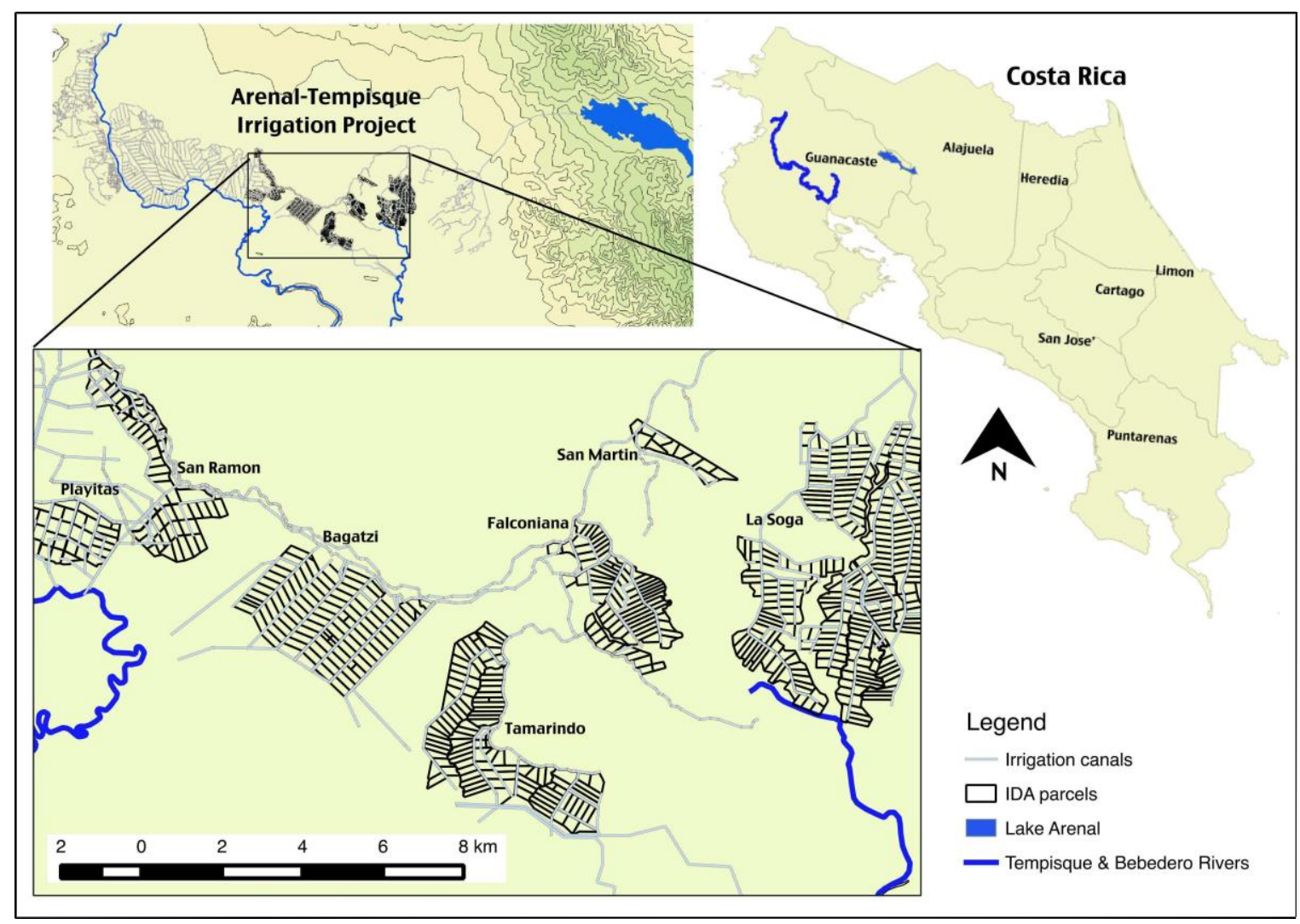

Figure 1 - Arenal-Tempisque Irrigation Project within the Tempisque River Basin in Guanacaste, Costa Rica; this map shows topography, PRAT canal infrastructure, and IDA-acquired parcels.

\subsection{Data collection}

We designed a household survey that allowed us to understand how household-level socio-economic variables correlate with transformative adaptations marked by a transition from rice production to sugarcane production following established guidelines (i.e., UN Department of Economic and Social Affairs, 2008). Our sampling frame consisted of smallholder farmers on IDA-acquired parcels within the PRAT, all of who produced rice or sugarcane during the time of our data collection. If a farmer being surveyed had transitioned to sugarcane production, questions were asked to collect socioeconomic data about their time as a rice farmer. Similar to Below et al. (2012), all questions were structured to collect socio-economic data that we categorized using Yohe 
\& Tol's (2002) determinants of adaptive capacity. Each survey also included a semistructured interview to gather farmer perspectives on their efforts to adapt to risks and on their values and perceptions of the future of smallholder farming in the PRAT. Following the iterative process defined by the United Nations Department of Economic and Social Affairs, we refined our interview questions and household survey design by holding three focus groups with smallholder farmers in February 2013. Each focus group lasted approximately one hour and included 4-8 farmers. Participants were smallholder farmers on IDA-acquired parcels who we knew through previous work in the region. In the focus groups, we asked farmers to talk openly about, and then attempt to reach a consensus description of, (1) their valued livelihood goals, and (2) the adaptations they employed to adapt to water scarcity and decreasing rice-market access.

The revised household survey was pre-tested by surveying five smallholder-farming households in the PRAT. We then further revised the survey based on the feedback from these farmers. The final survey was comprised of questions structured in order to collect socio-economic data including information about demography, assets and wealth, access to markets and services, and perceptions of climate risks. If farmers had switched to sugarcane production, they were asked to specify if the switch was in response to the debts accrued through a failed crop resulting from water scarcity, or in response to decreasing rice-market access, which focus group participants agreed were the only reasons farmers switch to sugarcane production.

We visited and requested interviews at every household in each of these seven IDAacquired districts (Figure 1). Each farmer represented in this study was interviewed only once. Interviews were held in farmers' homes or in their fields. In total, 114 surveys were administered from February to November 2013, and 94 were ultimately used. Surveys of individuals who did not own land provided by the IDA were not used in this analysis. Each survey lasted from 20 to 30 minutes. The interview portion of each visit lasted up to 1.5 hours. We audio recorded the interviews and the University of Costa Rica's School of Anthropology transcription service transcribed all recorded interviews.

\subsection{Data analysis}

Qualitative data consisted of focus group notes and interview transcripts from household interviews. Focus group notes were analyzed using the content analysis method described Sandelowski (2000). Focus group notes were coded using the NVivo 10 software (QSR International 2012). Codes were common insights and phrases about farmer values and adaptations. We clustered similar codes, and used these clusters to revise our interview questions. Interview transcripts were also coded using the NVivo 10 software according to emergent themes and our initial hypotheses associated with valued livelihood goals, adaptation limits, and transformative adaptations. We used government and industry statistics and published literature to validate interview-based narratives.

The data from the quantitative household survey were analyzed using descriptive statistical methods and logistic regression models. Frequencies of nominal socioeconomic variables and measures of the central tendency of scalar socio-economic 
variables were used to describe farmer socio-economic household characteristics and farm characteristics. This description was supplemented with data from focus groups. Predictors of farm transitions to sugarcane production were analyzed using IBM SPSS Statistics 22.0 software. Qualitative and contextual data were then used to describe these predictors as determinants by drawing assumed causal links between each predictor and a household switch to sugarcane production.

\subsubsection{Logistic regression models}

We analyzed and transformed quantitative farmer socio-economic data into independent variables to meet the assumptions of logistic regression, including assumptions of independence and non-co-linearity. Binary and multinomial logistic regression models were deemed to be appropriate for our analysis because continuous and categorical predictor variables were included in our model and our dependent variables were dichotomous and categorical. We analyzed the relative influence of the socio-economic variables on farm transitions from rice to sugarcane production using a binary logistic regression model. We used a multinomial regression model to determine correlations of predictors of farm transitions to sugarcane production due to both water scarcity and decreasing rice-market access.

The functional form of the logistic function we used was:

where was a "log odds" (i.e., the logarithm of the odds $p /(1-p)$, where $p$ is probability),

was constant, to were vectors of coefficients and was an error term. In this equation, the coefficient estimated change in log odds of the dependent variable, not the change in the variable itself. Therefore, we simplified the model by transforming it to an odds ratio using the exponential function:

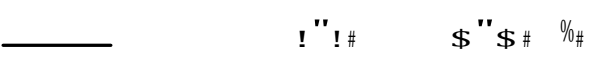

The odds ratio is the ratio of the probability that a household would transition to sugarcane relative to the probability that it would not convert. The multinomial logistic regression model utilizes two logistic functions of the same form, each relative to the reference group (rice production). We utilized a multinomial regression in this study because our dependent variable in question consisted of more than two categories (i.e., (1) rice production, (2) transition to sugarcane due to decreasing rice-market access, and (3) transition to sugarcane due to water scarcity).

For dichotomous independent variables in both models, the exponential of the respective coefficient gives the proportion of change in odds for a shift in the given variable. If the variable was scalar, both the coefficient and exponential of the coefficient were associated with the effect of per unit change. The sign of the coefficient revealed the 
direction of change in all variables. Socio-economic independent variables were incorporated into both logistic regression models to control for each category in Yohe \& Tol's (2002) framework in order to interpret the results in a way that held other important adaptive inputs constant. If multiple variables were included in one category, goodnessof-fit was analyzed with and without each variable, and variables were discarded if doing so improved goodness-of-fit within each category. The omnibus test and the Hosmer and Lemeshow goodness-of-fit test were used to test model fit and significance. The null hypothesis was that no relationship existed between a household transition to sugarcane and any socio-economic variable.

\section{Results and discussion}

\subsection{Smallholder farming in the Arenal-Tempisque Irrigation District}

The original goals of the Arenal-Tempisque Irrigation Project (Proyecto de Riego ArenalTempisque, PRAT), as defined by Costa Rica's government, were (1) to take advantage of the waters discharged by the hydroelectric dam at Lake Arenal; (2) to improve living conditions in the semi-arid Tempisque River Valley by generating agro-employment, redistributing land from large land owners to smallholder farmers, and changing cropping systems; and (3) to promote integrated regional development with complementary smallholder and agro-industrial sectors (Edelman, 1992). To reach these goals, the government provided smallholder farmers with parcels of land ranging in size from one to 12 hectares, and then the PRAT was to supply these parcels with irrigation water during the dry season (November-March). Market access was to be provided to smallholder farmers by agro-industries who relied on smallholder farms for the production of rice.

While these original goals of the PRAT never changed, the government's capacity to successfully achieve them did change. The Latin American debt crisis, beginning in the early 1980s, brought a restructuring of Costa Rica's economy, and along with it a restructuring of its agrarian institutions. The Costa Rican government abandoned many of its public-private partnerships in the PRAT in order to meet the economic restructuring demands of the International Monetary Fund, the World Bank, U.S.AID, and the InterAmerican Development Bank in return for financial support. Today, smallholder farmers in the PRAT are adapting to decreasing rice-market access and increasing water scarcity. These are the root causes of the vulnerability of smallholder farmers' represented in this study. While the study of Costa Rica's agrarian political economy is outside the scope of this paper, see Edelman, (1992 and 1999), Honey (1994), Warner et al. (2015), and Marois (2005) for rich descriptions of this process of neoliberal agrarian change.

\subsection{Interacting global change risks}

Since the PRAT began providing irrigation water to farmers in 1983, rice has been the crop of choice for the smallholder farmers represented in this analysis. In the early 2000s, almost all farmers in our case study produced rice (Arriagada, Sills, Pattanayak, Cubbage, \& González, 2010). This percentage has decreased and today, $40 \%$ of the farmers 
surveyed have transitioned to sugarcane production and many more claimed they would abandon agriculture within the next five years. These transitions were driven by the impacts of two interacting global change risks. First, a rapid vertical integration of industrialized rice mills has occurred in the region, brought about by State rice-policy responses to the Dominican Republic-Central America-United States Free Trade Agreement (see Warner et al., 2015; Hidalgo, 2014; Monge-González, Rivera, \& Rosales-Tijerino, 2010). This vertical expansion greatly limited rice-market access for smallholder farmers in the PRAT. Second, increasing regional drought has forced many rice farmers in the region to abandon rice crops between 2006 and 2014. The remaining smallholder rice farmers in the PRAT continue to plant rice because if they are able to grow and sell their harvest, they may earn a fair profit.

The successful production and sale of a 10-hectare rice harvest brought approximately US\$33,000 in 2012 (CONARROZ, 2012). Farmers typically sow and harvest two crops per year. Over $75 \%$ of their gross income covers input and milling costs, which provides smallholder farmers with stable livelihoods above Costa Rica's average gross national income of US\$8,820 (World Bank, 2012). However, without securing a sales contract from any one of the remaining five industrial rice mills in the region, they have no guarantee that their harvests will be purchased, and they must search for remaining capacity at regional mills after every harvest to sell their rice. In addition, the PRAT's highly vertically integrated rice mills now produce much of their own rice on irrigated land outside of IDA-controlled parcels. This means mills rely less on the purchase of smallholder-farm rice harvests. The limited amount of rice that is purchased by rice mills from smallholder farms is purchased early in the harvest season. This has created competition among smallholder farmers to harvest and sell rice earlier in the growing season before mills reach their production capacities.

\subsubsection{Interaction between decreasing rice-market access and increasing water scarcity}

The Tempisque River Basin experienced drought conditions in seven of the nine years from 2006 and 2014. Regional climate models predict higher temperatures and water deficits in the next several decades (Anderson, et al., 2008). Wet season precipitation is expected to decrease significantly during this time, creating soil-moisture deficits and reducing the amount of surface water available for irrigation by half (Karmalkar et al., 2008). Climatic and hydrologic changes are already apparent in the Tempisque River Basin and farmers represented in this study overwhelmingly recognized it: $99 \%$ of farmers interviewed perceived decreases in rainfall and almost $90 \%$ perceived warmer temperatures over the last decade in comparison to previous years.

Beginning in September 2006, for the first time, the PRAT operated under conditions of water scarcity. The PRAT water managers devised a plan to cycle irrigation water by sector in an attempt to provide farmers with enough water to plant and harvest and not lose harvests. Water shortages primarily occurred during the high water demand months of December and January, during which time both rice and sugarcane are planted. Both crops require large inputs of water during planting, and rice must be planted near the start of the dry season so it can be harvested prior to the beginning of the next rainy season, 
which usually begins in May. The water-cycling program was designed to spread farmerplanting dates across a series of 6 weeks, thereby allowing all farms to successfully plant and harvest prior to the beginning of the next rainy season. Allocation priorities are created anew each December when agronomists, employed by the PRAT water management to oversee the seven IDA districts, meet to determine which sections of the districts to prioritize during the water-cycling program. Interviews with water managers indicated that this process was "fluid," as no legal precedent exists to dictate allocation priorities. While this water-cycling program could allow all smallholder farmers to plant their rice crops and harvest before the rains begin, farmers who are forced to wait to plant have more difficulty selling their harvests because their later harvest dates limit their ability to sell their consequently later harvests before rice mills stop buying smallholder rice harvests for the season. And, while it is possible for smallholder farmers to store their production, the debts accrued each season necessitate the timely sale of their harvests.

Delayed water allocations, in combination with limited access to the rice market during harvest, have caused water piracy among farmers throughout the PRAT. This has created water scarcity for some. Farmers upstream in the PRAT illegally modify irrigation infrastructure to gain early access to water allocations (Figure 2 shows examples from February 2012 and December 2013). Many farmers furthest downstream plant rice but then lose their water access as a result of these actions of upstream farmers, and therefore many downstream farmers have been forced to abandon rice crops.
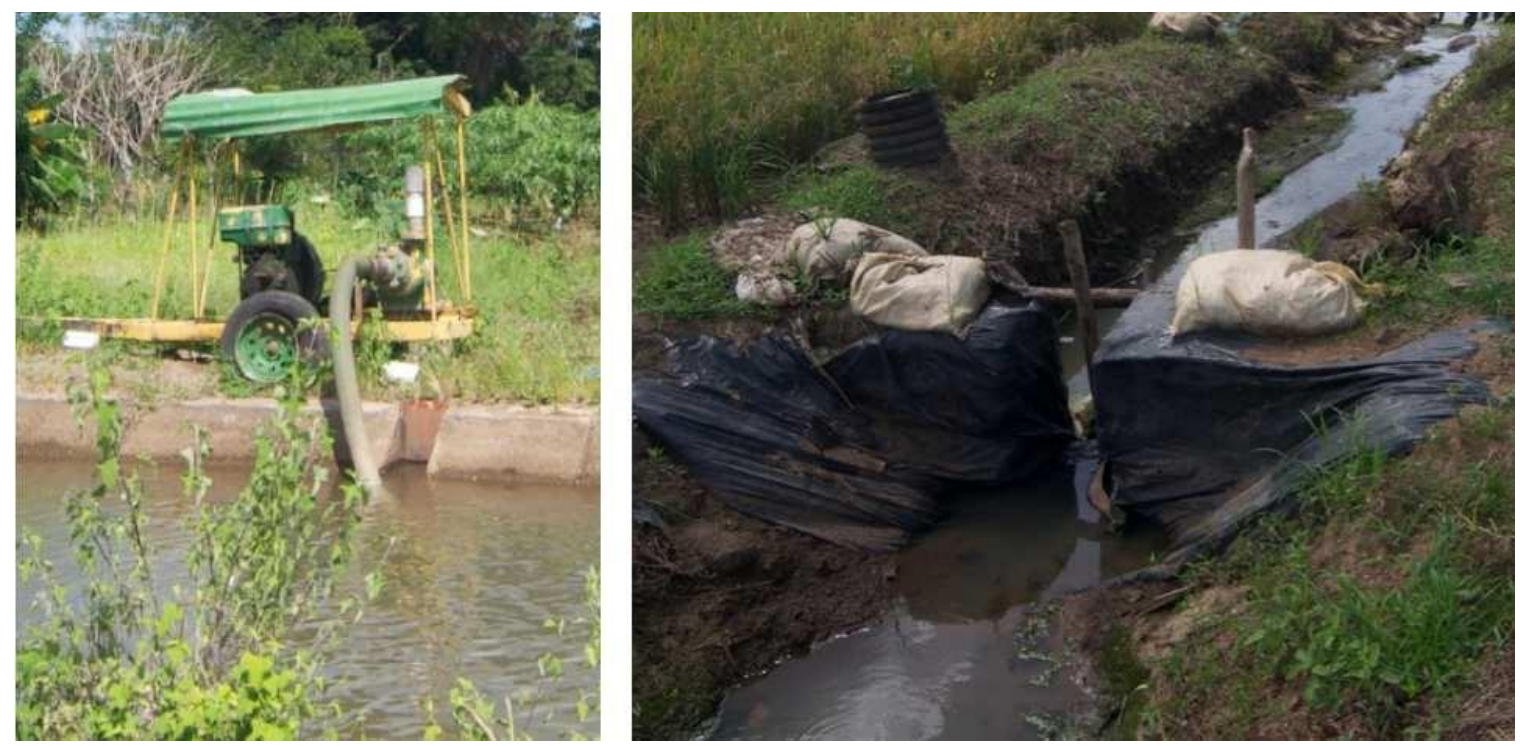

Figure 2 - The picture on the left is of a pump illegally drawing irrigation water from a PRAT canal; when water managers are not patrolling the canals, farmers can use pumps to transport water from the canals to their crops during the cycling process, and this limits water availability downstream. The picture on the right is of a makeshift dam, built by a farmer in a remote region of the irrigation district (an area that is infrequently patrolled). Farmers build these dams to gain access to water, and their neighbors typically destroy them as they are affected by the water loss. Photos by Benjamin Warner. 
One farmer described this upstream advantage during times of water shortage in reference to the rice market and his neighbors.

"If the water shortage is large, I take what I need. I have problems with my neighbors, but I take what I need because I cannot sell if I wait. My neighbors are not very patient." (Interviewee \#22, 2-hectare rice farmer, upstream in the PRAT, February $16^{\text {th }}, 2013$ )

Another farmer described his frustration with the actions of his upstream neighbors during times of water scarcity, again referencing decreasing rice-market access.

"The problem was that it was a very bad winter (May-August is referenced by farmers as winter), and the lagoon, which is the reservoir for the PRAT was very low. SENARA (PRAT water managers) started giving us water once every 4 days. But as I am at the end of the channel, there was almost no water for me. I lost half of my crop and I have no rice-purchase contract. I do not know what I will do." (Interviewee \#15, 7-hectare rice farmer, downstream in the PRAT, February $11^{\text {th }}$, 2013)

\subsection{Limits to adaptation}

The transition of smallholder rice production to sugarcane production is brought about by one of two impacts: (1) the debt accrued through the inability of a farmer to sell their rice harvest, or (2) through the loss of one or more rice crops to water scarcity. When a smallholder farmer switches to sugarcane, they do so by entering into long-term $(>10$ years) full-land-management-production contracts with one of three industrialized sugar mills in the PRAT. Such contracts between smallholder farmers and sugar mills typically include the purchase of the smallholder farmer's rice debts. The sugar mills then plant, manage, and harvest smallholder farm fields, and smallholder landowners receive a flat fee per hectare depending on their debt. On average they receive approximately US $\$ 300$ per hectare per year, which equates to earnings well below the Costa Rican poverty level for the majority of smaller landholding sizes (i.e., $10 \mathrm{Ha}=\mathrm{US} \$ 3,000$ / year).

Farmers and PRAT managers overwhelmingly agree that a strong smallholder-farming sector is needed in the PRAT because it would promote Costa Rican food security and bolster the region's non-migrant based economy. Farmers in our focus groups agreed that their most valued livelihood goals were (1) security of education, healthcare, and the maintenance of assets and land for family members, and (2) the maintenance of their identities as parcelaros (i.e. smallholder farmers who were given land or who were sold land at discounted rates by the government). Household interviews further verified these findings and provided rich insights into these values. The preservation of livelihood security was a primary concern among smallholder farmers because many had suffered livelihood setbacks between 2002 and 2012, and most were worried about the impacts of future risks. Many farmers cited recent examples of neighbors' misfortunes and resulting abandonments of farming. Participants also referenced the past and a perceived disappearance of their "parcelaro identity." In these references, farmers portrayed 
themselves as rice farmers that were being forced out of their trade by the Costa Rican government, international rice imports, and rice mills. Torres (1997) showed that most parcelaros throughout the 1990s refused all efforts by the Ministry of Agriculture to provide extension services to assist in a transition to "non-traditional" crop types, as is required by the demands of the Costa Rican economic restructuring. Extension agents promoted non-traditional agriculture as a means to increase the production of internationally valuable crop types, but parcelaros refused, citing their history in rice production.

This parcelaro identity is unique among Costa Rican farmers, and it reflects the wider Guanacasteco identity - one of conservative self-reliance - that characterizes the longstanding agrarian culture of Guanacaste Province. Guanacaste, and specifically the Tempisque River Basin, is rich in arable land, with large expanses of flat, fertile alluvial soils, so agriculture is the primary economic sector within the region. Parcelaros have traditionally considered themselves the "last holdout" in Costa Rica against increasingly globalized agriculture (see Edelman, 1992 \& 1999 for rich historical descriptions of smallholder agriculture in Guanacaste). In this context, parcelaros referenced their identity as self-reliant, community-oriented, loyal to their own, and deeply respectful of their lands and environment. This identity is unique to rice production in Northwest Costa Rica because parcelaros perceive rice to be of great importance to Costa Rican culture and food security, and less impactful on the Guanacaste environment. While the validity of these perceptions has been challenged (see Jiménez, González, \& Mateo-Vega, 2001), this pride was evident among farmers in this study. Participants referenced a transition to sugarcane as giving up on these values. One farmer explained why his decision to continue to farm rice entailed more than profit.

"Even though the banks no longer finance rice [for smallholder farmers], and even though everyone who used to buy rice no longer does so, I still sow rice. Now some people tell me to plant sugarcane, but the sugarcane impoverishes the land and the sugarcane removes the vitamins from the land. It is like I will be removing the food from the land. That is why I grow rice, even if I will not gain what I used to. Here in Bagatsí, it is not worth it, it is not worth it. I do not ever sow sugarcane” (Interviewee \#25, 11.2-hectare rice farmer, February 17 ${ }^{\text {th }}, 2013$ ).

Another farmer explained his traditional ties to rice production, and contrasted this with his perceptions of the environmental damage caused by the harvest of sugarcane (sugarcane fields are burned before harvest to remove leaves).

"I do not like sugarcane in the least. For me, I do not like sugarcane because I have always sowed rice, and I always like to see it grow. When you flood [the rice paddy], it is something that is totally beautiful, when it sprouts and you see the green-beautiful. Sugarcane is not this way. I do not like what sugarcane does to the environment. When they burn [sugarcane], and then when they cut the sugarcane it is extremely, for me, it is extremely polluting. Because when they harvest, even [when they harvest sugarcane] miles from here, you just see smoke, 
and we are surrounded by about 2000 hectares, or more than 2000 hectares of sugarcane" (Interviewee \#64, 5-hectare rice farmer, March $8^{\text {th }}$, 2013).

A third farmer describes the process of transition to sugarcane production in the PRAT and compares this with his own values.

"Before, this area used to be all rice. Now it is all sugarcane, and rice will disappear. Why? Because there is no financial support, you cannot sell it, the government lets in rice from other countries and they forget the small producer. Sugarcane has some advantages-you rent your land to the ingenio and they take care of everything, but I lose everything” (Interviewee \#22, 2-hectare rice farmer, February $16^{\text {th }}, 2013$, note: 'ingenio' is Taboga S.A., the largest industrial sugarcane producer in Costa Rica, see TABOGA, 2014).

Allowing smallholder farmers to achieve these livelihood goals would promote the goals of the PRAT management. Despite this seemingly unanimous agreement regarding the importance of smallholder-rice farming in the PRAT, few solutions have been proposed to help farmers overcome the impacts of water scarcity and decreasing rice-market access. This has left farmers struggling to adapt to these impacts with little support from local, regional, or national institutions. Because of this, many have reached the point at which their valued livelihood goals cannot be met through adaptive actions, thereby forcing a transition to sugarcane production. A farm-transition to sugarcane production most often forced farmers to sacrifice both valued livelihood goals (which also often resulted in food insecurity and poverty), or to trade-off their identities for the possibility of financial security and to seek alternative employment if those opportunities existed.

The transition to sugarcane production represents a long-term loss of the smallholder ricefarmer parcelaro identity. While smallholder farmers could independently plant sugarcane (rather than transfer their land to sugarcane mills) and independently sell it to a mill, the price they would receive for their crop renders this option prohibitive. Given the high costs of human and mechanical inputs that are unique to sugarcane, labor and machinery must be utilized efficiently on larger scales to profit from sugarcane production. This creates the opportunity for agri-business to exploit economies of scale in the sugarcane production line by spreading high capital and management costs over a large tonnage (Moor, 1998). Approximately 50\% of sugarcane grown in the region is cut manually (TABOGA, 2014) by migrant workers. The remainder is cut and windrowed mechanically, requiring substantial fixed capital investments by mills. These investments require years of harvests to become profitable. Therefore, sugar mills seek only long-term land management contracts from smallholders; there are currently no short-term options to transition smallholder agriculture to sugarcane. There is substantial irreversibility in the transition to sugarcane that entails the loss of both livelihoods and parcelaro identities. Furthermore, few alternatives to rice or sugarcane production exist for parcelaros that may allow them to better manage the impacts of global changes. For these reasons, we consider farmer abandonment of rice production through the transition to sugarcane production a transformative adaptation, which marks an adaptation limit in this context. 


\subsection{Determinants of transformative adaptation}

In our household survey, we asked farmers who had transferred their land rights to sugar mills to describe why they did so. While many farmers who had switched to sugarcane production reported to have suffered losses from both water scarcity and decreasing ricemarket access, all could attribute a majority of their livelihood losses and their ultimate transition to sugarcane production directly to one of the two impacts. In all, $40 \%$ of all farmers surveyed had transitioned to sugarcane, and $45 \%$ of them switched due to the loss of one or more rice crops to water scarcity. The remaining 55\% reported that they had switched to sugarcane production because they had accrued insurmountable debts due to the inability to sell their rice crops. It was apparent during our data collection that this transformative adaptation had forced many farmers into conditions of food insecurity and poverty. There was also evidence (e.g., vacant homes on sugarcane producing parcels) of out-migration. While these farmers were not included in our study, it is important to point out that some farmers did appear to have the capacity to transition out of agriculture and migrate from the region.

We assumed that some household-scale socio-economic variables (Table 1), collected through our household survey, would be predictors of farm transitions to sugarcane production, and we used logistic regression models to assess the correlation of each to this transformative adaptation. Also, we coded each independent variable using Yohe \& Tol's (2002) determinants of adaptive capacity in order to discuss our findings in the context of our theoretical framework. In total and as described below, we found that four of the 15 socio-economic variables shown in Table 1 were predictors of farm transitions to sugarcane production in the PRAT.

Table 1 - Household-scale socio-economic variables expected to be significantly correlated with farmers' coping mechanisms, $\mathrm{N}=94$

\begin{tabular}{|c|c|c|c|c|}
\hline $\begin{array}{l}\text { Categorical socio-economic } \\
\text { independent variables } \\
\text { Owns land }\end{array}$ & $\begin{array}{l}\text { Determinant } \\
\text { following Yohe } \\
\text { and Tol (2002)* } \\
\text { D2 }\end{array}$ & Response category & Count & Percent \\
\hline & & $1=$ Yes & 75 & 79 \\
\hline \multirow[t]{2}{*}{ Owns equipment } & \multirow[t]{2}{*}{ D1, D2 } & $0=\mathrm{No}$ & 54 & 57 \\
\hline & & $1=$ Yes & 40 & 43 \\
\hline \multirow[t]{2}{*}{ Has crop insurance } & \multirow[t]{2}{*}{ D6, D3 } & $0=\mathrm{No}$ & 60 & 64 \\
\hline & & $1=$ Yes & 34 & 36 \\
\hline \multirow[t]{2}{*}{ Cattle ownership } & \multirow[t]{2}{*}{$\mathrm{D} 2$} & $0=\mathrm{No}$ & 44 & 47 \\
\hline & & $1=$ Yes & 50 & 53 \\
\hline \multirow{2}{*}{$\begin{array}{l}\text { Only receives market } \\
\text { information from purchaser of } \\
\text { harvest }\end{array}$} & \multirow[t]{2}{*}{ D6 } & $0=\mathrm{No}$ & 30 & 32 \\
\hline & & $1=$ Yes & 64 & 68 \\
\hline \multirow{2}{*}{$\begin{array}{l}\text { Formal agriculture training } \\
\text { among any member of household }\end{array}$} & \multirow[t]{2}{*}{$\mathrm{D} 4$} & $0=\mathrm{No}$ & 70 & 75 \\
\hline & & $1=$ Yes & 24 & 25 \\
\hline \multirow[t]{2}{*}{ Friends outside of farming** } & \multirow[t]{2}{*}{ D5 } & $0=\mathrm{No}$ & 67 & 71 \\
\hline & & $1=$ Yes & 27 & 29 \\
\hline \multirow{2}{*}{$\begin{array}{l}\text { Relatives with livelihoods } \\
\text { outside of farming }\end{array}$} & \multirow[t]{2}{*}{ D6 } & $0=$ No & 53 & 56 \\
\hline & & $1=$ Yes & 41 & 44 \\
\hline
\end{tabular}




\begin{tabular}{|c|c|c|c|c|c|c|c|c|c|c|}
\hline \multirow[t]{2}{*}{ Agriculture is sole income source } & \multirow[t]{2}{*}{ D6 } & \multicolumn{4}{|l|}{$0=\mathrm{No}$} & 18 & \multicolumn{4}{|l|}{19} \\
\hline & & \multicolumn{4}{|l|}{$1=$ Yes } & 76 & \multicolumn{4}{|l|}{81} \\
\hline \multirow{2}{*}{$\begin{array}{l}\text { Perception of precipitation } \\
\text { decrease }\end{array}$} & \multirow[t]{2}{*}{ D8 } & \multicolumn{4}{|l|}{$0=\mathrm{No}$} & 1 & \multicolumn{4}{|l|}{1} \\
\hline & & \multicolumn{4}{|l|}{$1=$ Yes } & 93 & \multicolumn{4}{|l|}{99} \\
\hline \multirow{2}{*}{$\begin{array}{l}\text { Perception of temperature } \\
\text { increase }\end{array}$} & \multirow[t]{2}{*}{ D8 } & \multicolumn{4}{|l|}{$0=\mathrm{No}$} & 10 & \multicolumn{4}{|l|}{11} \\
\hline & & \multicolumn{4}{|l|}{$1=$ Yes } & 84 & \multicolumn{4}{|l|}{89} \\
\hline $\begin{array}{l}\text { Scalar socio-economic } \\
\text { independent variables }\end{array}$ & Determinant & Mean & $\begin{array}{l}\text { Std. } \\
\text { Dev. }\end{array}$ & Range & Min & Max & $\begin{array}{l}20 \\
\%\end{array}$ & $\begin{array}{l}40 \\
\%\end{array}$ & $\begin{array}{l}60 \\
\%\end{array}$ & $\begin{array}{l}80 \\
\%\end{array}$ \\
\hline Years spent farming & D7 & 22 & 7.2 & 34 & 2 & 36 & 17 & 22 & 22 & 28 \\
\hline Age of head of household & D7 & 51 & 14.3 & 63 & 20 & 83 & 38 & 49 & 55 & 62 \\
\hline Children in household & D4 & 2.9 & 1.9 & 10 & 0 & 10 & 2 & 2 & 3 & 4 \\
\hline $\begin{array}{l}\text { No. of household members who } \\
\text { work on farm }\end{array}$ & D4 & 0.8 & 1.4 & 8 & 0 & 8 & 0 & 0 & 1 & 2 \\
\hline Size of Farm & D2 & 8.8 & 8.0 & 49.2 & 0.8 & 50 & 2.5 & 5 & 10 & 13 \\
\hline
\end{tabular}

*(D1) available technological options for adaptation, (D2) resources and their distribution, (D3) critical and functional institutions, (D4) human capital including education and security, (D5) social capital including the definition of property rights, (D6) access to risk spreading processes, (D7) ability and credibility of decision-makers to manage information, and (D8) perceived attribution of the source of stress and the significance of exposure.

** Farmer has close friends outside of farming that they visit at least four times per year.

In our analysis of predictors of farm transitions to sugarcane, or transformative adaptation, we first explored predictors of all farm transitions to sugarcane production included in our study. This analysis included all farms that transitioned to sugarcane production for any reason and those that continued to plant rice at the time of the survey. This analysis showed that three predictors were significantly correlated with farm transitions to sugarcane: cattle ownership, agriculture as a principle income source, and years spent farming (Table 2).

Table 2 - Parameter estimates from binary logistic regression model, N=94

Change crop type to sugarcane: total $(0=$ no change to sugarcane; $1=$ change to sugarcane)

\begin{tabular}{|l|l|l|l|l|l|l|l|l|}
\hline Predictors & B & S.E. & Wald & Z & Sig. & \multicolumn{2}{|l|}{ Exp(B) } & \multicolumn{2}{|c|}{ 95\% C.I. } \\
Cattle ownership & -0.971 & 0.38 & 6.522 & 2.554 & $0.011^{* *}$ & 0.379 & 0.18 & 0.798 \\
\hline No. of household members on farm & -0.659 & 0.429 & 2.356 & 1.535 & 0.125 & 0.517 & 0.223 & 1.2 \\
\hline Size of Farm & 0.037 & 0.037 & 1.003 & 1.001 & 0.317 & 1.037 & 0.966 & 1.114 \\
\hline Agriculture is/was sole income & 0.536 & 0.244 & 4.84 & 2.200 & $0.028^{* *}$ & 1.709 & 1.06 & 2.754 \\
\hline Owns equipment & 0.539 & 0.599 & 0.81 & 0.900 & 0.368 & 1.714 & 0.53 & 5.548 \\
\hline Friends outside of farming & 0.096 & 0.537 & 0.032 & 0.179 & 0.858 & 1.101 & 0.385 & 3.153 \\
\hline Years spent farming & -0.307 & 0.13 & 5.575 & 2.361 & $0.018^{* *}$ & 0.736 & 0.571 & 0.949 \\
\hline Perception of temperature increase & 19.302 & 11740 & 0 & 0.000 & 0.999 & - & - & - \\
\hline Has crop insurance & -0.483 & 0.604 & 0.639 & 0.799 & 0.424 & 0.617 & 0.189 & 2.017 \\
\hline Formal educational training in household & -0.948 & 0.679 & 1.951 & 1.397 & 0.162 & 0.388 & 0.103 & 1.465 \\
\hline Age of head of household & -0.021 & 0.023 & 0.826 & 0.909 & 0.363 & 0.979 & 0.936 & 1.025
\end{tabular}

*Significant at the 0.10 level; **Significant at the 0.05 level

Cox \& Snell R Square 0.396, Nagelkerke R Square 0.533

Omnibus tests of model coefficients: Chi-square 47.411, df 11, Sig. 0

Hosmer and Lemeshow Test: Chi-square 3.615, df 8, Sig. 0.89

Farms that had cattle (data included those that had cattle before their transition from rice production to sugarcane because some farms sold their herds before the transition) were $62 \%$ less likely to transition to sugarcane production. Among rice farmers in the PRAT, 
cattle were used as buffers against the impacts of risks. Cows were the only type of livestock reared by farmers in our study, and they were regularly bought and sold between farms and at regional auction houses. Farmers did so, in large part, to pay off debts assumed through the inability to sell a rice crop, or for income if a farm lost rice crops to water scarcity. In global change research, selling cattle is often considered a coping mechanism, in contrast to an adaptation in pursuit of an opportunity. This consideration is often assumed because cattle are capital, and by selling cattle farmers may then become more vulnerable to future impacts. In this way, it is assumed farming households follow traditional risk management strategies of income diversification farmers supplement their crop income with livestock income. While these processes were occurring among some farmers in this study, most farmers we surveyed perceived cattle as supporting their rice-crop production. They did not perceive cattle as a part of their identities. This distinction is important. We had originally classified cattle per Yohe \& Tol's (2002) adaptive capacity classification as a resource that made farms more adaptive to risks in the traditional sense. However, among farmers in the PRAT, the process of cattle rearing operates more as a strategy to preserve rice production-based livelihoods. The rich history of cattle rearing in Guanacaste provides ease of market access and an established and accessible knowledge base for raising cattle. The renewable nature of the resource seems to draw farmers to invest in cattle rather than other types of economic or physical capital that may provide buffers to their rice production. Farmers often described cattle ownership as a premeditated coping mechanism. For example, one farmer described smallholder cattle rearing within his livelihood in this way:

"The small cattleman is extinct [in the PRAT]. I own cattle because rice is bad business, and I am a rice farmer. " (Survey respondent \#53, 14-hectare rice farmer, March $1^{\text {st }}, 2013$ )

Another farmer provided a description of the role cattle play in his ability to avoid losses due to water scarcity.

"I lose my harvest [to water scarcity], but I have 11 Brahman and a Parda so it doesn't matter, we can still eat." (Survey respondent \#56, 1.4-hectare rice farmer, March $3^{\text {rd }}, 2013$ )

A second significant determinant of transitions to sugarcane production was a sole reliance on farm-related income before the transition. Those rice farmers who solely relied on farm-related income were nearly twice as likely (e.g., 1.7 times) to transition to sugarcane compared to those farmers with multiple income sources. Yohe \& Tol (2002) showed that access to risk-spreading processes was a determinant of adaptive capacity, and we categorized diversified income sources as such (similar to our re-categorization of cattle). A majority of farms represented in this study relied solely on farm-related income, but twenty percent of farms had diversified their income sources beyond agriculture. This allowed them to spread the risks of both water scarcity and decreasing market access. This risk-spreading process better allowed these farming households to continue to meet their valued livelihood goals of livelihood security and identity retention. Often cited methods of livelihood diversification among households 
represented in this study were chambas (i.e., odd-jobs), and transportation- and tourismsector employment, but other, more permanent livelihood transitions were also considered. For example, one farmer viewed his son's education as a way to bolster future income while continuing to produce rice.

"If I do nothing, we will be unable to produce rice after 2020, so I have sent my son to school to study accounting. He will work so we can farm." (Survey respondent \#61, 8-hectare rice farmer, March $7^{\text {th }}, 2013$ ).

We found that the number of household members who worked the farm was not significantly correlated with a transition to sugarcane. In contrast, Eakin (2006) found that among irrigated farms in Mexico, labor-intensive farming prohibited diversification because it demanded more household labor to be dedicated to production. However, farmers who transitioned to less intensive production gained opportunities to diversify, which in turn subsidized agricultural production. Rice production in the PRAT is very household-labor and time intensive, and a transition to sugarcane frees this labor. Many of the farmers interviewed in this study had recently transitioned to sugarcane, and so many were still in the process of adapting household labor. However, there was some evidence of this labor adaptation process as some farmers were pursuing employment in alternative economic sectors.

The third significant determinant of transition to sugarcane production in this study was years spent farming by the head of the household. We classified this determinant as "the ability and credibility of a decision-maker to manage information" within Yohe \& Tol's (2002) classifications of adaptive capacity. Farmers included in this study had farmed from as little as 2 years to as long as 36 years. We had assumed that the increased experience and knowledge that comes from more "years spent farming" would better allow these farmers to manage risk and make good decisions, allowing them to continue farming. However, many of the farmers included in this study who had farmed the longest also resided in Agricultural Development Institute (Instituto de Desarrollo Agrario, IDA) sectors that were first incorporated into the PRAT in 1983. Within our sampling frame, these sectors had a higher percentage of rice growers compared to more recent IDA land acquisitions. So, while experience may have played a role in the ability of a farmer to avoid the livelihood losses, it seemed collective action was also incorporated into this variable. Rice farmers in the oldest sectors seemed better organized in the production process. They cooperatively rented and shared planting and harvest equipment. This cooperative system may have allowed rice farmers to better adapt. In contrast, those farmers who were beginning to farm on recently acquired parcels and who had not yet had the opportunity to acquire key assets and relationships to face significant insecurity may have been drawn to forfeit their parcelaro identities to pursue alternative livelihoods.

\subsubsection{Decreasing rice-market access-driven transformative adaptations}

Twenty-two percent of all farms included in this study transitioned from rice to sugarcane production as a result of decreasing rice-market access. Our analysis found two predictors 
of this transition among those farmers: size of farm and cattle ownership (Table 3).

Farmers that owned cattle were 56\% less likely to transfer their land to sugar mills for reasons described above.

Table 3 - Parameter estimates from multinomial logistic regression model, N=94

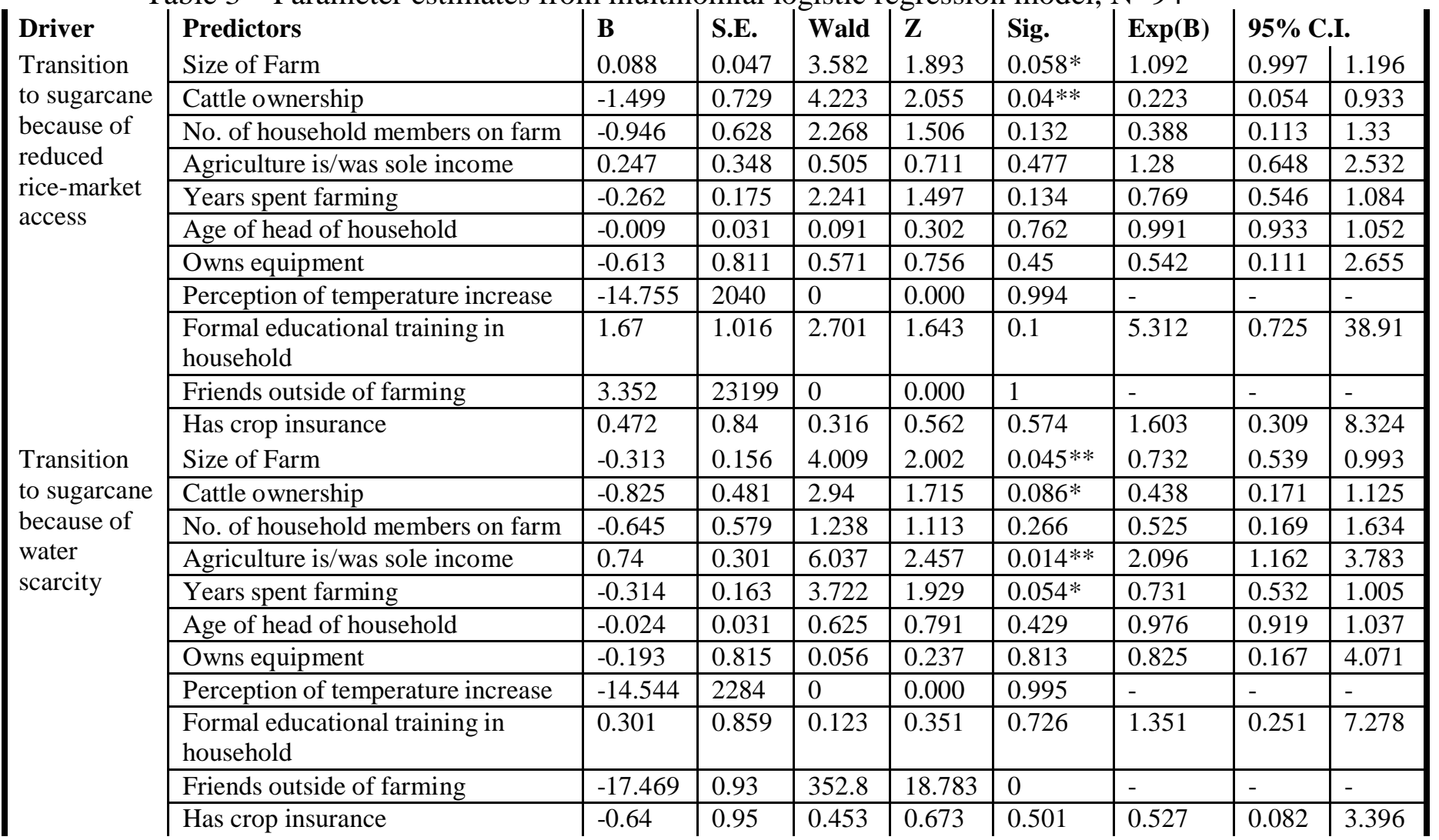

Reference category is: Rice producer

*Significant at the 0.10 level; **Significant at the 0.05 level

Cox \& Snell R Square 0.576, Nagelkerke R Square 0.674, McFadden 0.445

Goodness-of-Fit: Pearson Chi-square 194.938, df 160, Sig. 0.031

Increasing farm size was significantly correlated with transformations to sugarcane production due to the impacts of decreasing rice-market access. For every hectare increase in farm size, a farm was 1.1 times more likely to transition to sugarcane production. Larger farms included in this study, over ten hectares, were typically mechanized and they relied greatly on labor from outside the household. Farmers would assume large debts through the planting and harvesting of rice each season. Average debts assumed by farms were US $\$ 2,679$ per planted hectare (CONARROZ, 2012). The successful sale of a 10-hectare rice harvest could bring up to US $\$ 33,000$ in gross income. This income was used to pay debts and to support household livelihoods. Larger farms that were unable to sell their rice crops were sometimes able to access credit to pay their debts, and then sell their harvests to one of the remaining rice mills during the next harvest. However, the inability of larger farms to sell multiple rice crops often left them with insurmountable debts. Larger smallholder farms (e.g., > $10 \mathrm{Ha}$ ) would often transition to sugarcane production because of these debts. 


\subsubsection{Water scarcity driven transformative adaptations}

Eighteen percent of farmers surveyed had transitioned to sugarcane production as a result of lost rice crops due to water scarcity. We found four significant predictors of farmer transitions to sugarcane in this context (Table 3). Cattle ownership, farm is sole income, and years spent farming were again found to have significant correlations. The fourth determinant was size of farm. Larger farms were less likely to suffer losses from water scarcity. As described above, larger farms represented in our study were largely mechanized, and most had access to good credit. Most highly mechanized smallholder farms installed and relied on wells and surface water sources on their properties to supplement irrigation water. These larger farms typically had the capital and expertise to install wells. Although well installation is illegal in most instances according to Costa Rican law, such laws are rarely enforced. Larger farms may also have had the political capital necessary to avoid enforcement. Smaller farms included in this study, less than five hectares, rarely relied on groundwater to supplement their water supplies because they lacked the resources to access it. Few had access to credit, and none could afford the cost of well installation and operation. Smaller farms sometimes pumped water from surface water sources if they were fortunate enough to have access to a river or stream, or from the canals if they were upstream in the irrigation system and chose to engage in water piracy.

When water managers implement the PRAT water-cycling program during December and January to save water, smaller farms downstream are made vulnerable to water scarcity. Many lose their access to irrigation water during planting due to the now commonplace practice of water piracy. Smaller farms are often forced to abandon their harvests if they plant rice with the expectation of receiving irrigation water, but then fail to receive that allocation due to upstream water piracy. Through interviews with the smallest farm households, we learned that these farms are typically able to avoid debts when they lose rice crops because much of the planting is done by household labor, and they are relatively non-mechanized. However, while the loss of a rice crop does not in itself indebt smaller farming households, the loss of a rice crop means the loss of household income for the season. This income loss is why many of the smallest farms have given up their rice-production livelihoods and have transitioned to sugarcane production.

Among those rice farmers most vulnerable to water scarcity in the PRAT, many were able to cope with lost crops for multiple seasons through a process of rain-fed subsistence farming. Ultimately, though, a "retreat" to sugarcane often resulted after multiple seasons of attempting to cope. These farmers sacrificed independent agricultural identities, but gained the income security of US $\$ 300$ per hectare per year. Unfortunately, this security often appeared to come at the price of poverty, unless smallholders were able to diversify their livelihoods.

\subsection{Adapting to water scarcity, the "Catch-22" of successful adaptations to interacting risks in the PRAT}


In our analysis, size of farm was shown to be a determinant of farm transitions to sugarcane production. This transition was driven independently by both water scarcity and decreasing rice-market access, but the nature of this transition was contradictory. Those farms with more debt were more vulnerable to decreasing rice-market access, but they were better able to adapt to water scarcity due to their increased access to resources. Smaller farms, with fewer resources and that were heavily reliant on household labor, were shown to be better able to cope with the impacts of decreasing rice-market access, and yet were more vulnerable to the impacts of water scarcity. From the perspective of farmers most vulnerable to water scarcity in the PRAT, this situation is akin to Heller's (1961) "Catch-22." As smallholder farmers pursue their valued livelihood goals, which are structured around rice farming, the pursuit of increased rice production efficiency through mechanization or through the purchase or rental of additional land and resources would make them more vulnerable to the impacts of decreasing rice-market access. If farmers attempted to expand their farms and grow their livelihoods, they would accrue debts that may ultimately undermine their livelihoods if they failed to sell a rice crop. However, without attempting to expand their livelihoods by making investments in either additional land (to gain access to surface water) or in wells or water saving technologies, they would continue to be vulnerable to the impacts of water scarcity. This, also, could undermine their livelihoods and ultimately force transformative adaptations.

We did not see that medium-sized farms (i.e., six to ten hectares) in the PRAT were less susceptible to both forms of risk. There seemed to be a threshold above which farmers produced sufficient surplus to have more clout in rice markets, which required some specialization of labor and capital. Therefore, no smallholder farms, regardless of size would be viable in rice markets since mills were increasingly selecting larger rice producers. Smallholders who could not participate in the rice market were forced to diversify to meet livelihood stability goals or to become sugarcane producers. Both may be considered adaptations to stabilize volatility rather than get out of poverty or increase wealth. Ultimately, it is the combination and interaction of both risks that has forced these farmers to face adaptation limits in the PRAT.

The two primary challenges faced by PRAT managers in developing a sustainable solution to these problems are (1) the region's increasing aridity, and (2) a lack of authority to change rice-market access in the PRAT. The volume of Lake Arenal, the source of PRAT irrigation water, is predicted to continue to decrease over the next decades (Karmalkar et al., 2008). This will increase the frequency of water-cycling strategies in an attempt to address scarcity, further delaying rice planting each season for a certain number of farmers. If water allocations further push rice-planting dates each year, farmers will be forced to harvest in the rainy season, thereby requiring them to pay expensive drying fees or to abandon their harvests. Decreasing rice-market access among smallholder farmers is driven by Costa Rican policy and political responses to international trade liberalization, and these decisions are made at the national scale. PRAT managers have little authority over national rice-market policies, even though the PRAT produces $45 \%$ of the rice consumed in Costa Rica.

\section{Conclusion}


Smallholder farmers in the Arenal-Tempisque Irrigation District in Northwest Costa Rica face interacting risks to their livelihoods. Although maintaining rice-based livelihoods under conditions of increasing economic and climatic stress would be difficult in any context, the farmers represented in this study value rice production as more than a means for livelihood security. They perceive rice production as an identity, and they are being forced to consider limits to their abilities to adapt to maintain that identity. And, given a lack of alternative livelihood options in the region, confronting adaptation limits in this context also means large reductions in farm-based income. For those households most vulnerable to water scarcity, their ability to successfully adapt to meet valued livelihood goals is further diminished because adaptation to water scarcity increases vulnerability to decreased market access. In this way, they are trapped by vulnerability to risks of the interaction between global changes, and many will likely abandon valued identities for a semblance of livelihood security. Therefore, we conclude that Morton (2007) was correct in his proposition that farmer adaptations to climate change cannot be understood without incorporating the impacts of multiple global changes and place-based complexity.

We show that valued livelihood goals are crucial to understanding adaptation limits. Farmers represented in this study agreed that preserving their rice-farmer identities were valued goals, and these goals aligned closely with the development objectives of the PRAT. However, farmer goals of livelihood security for their households did not entirely depend on agriculture. Some farmers explored other livelihood opportunities as they transitioned to sugarcane production, and some farmers traded their valued identities to seek more secure livelihood sources. More research is needed to understand how farmers trade off valued livelihood goals as they make critical decisions to adapt when they are at adaptation limits, how much heterogeneity in a person's livelihood matters for identity, the household-decision-making process at adaptation limits, and the costs that a person is willing to incur in order to maintain an identity. As rural development programs are increasingly impacted by multiple, interacting global changes, this interplay among global change risks can stand as a barrier to farmer livelihood goals and to achieving sustainable rural development. The development and application of narrow solutions to singular risks will prove fruitless if they do not address underlying causes of problems or the crucial interactions between these multiple risks. A more holistic approach is needed to understand and manage rural development programs in the context of interacting global change risks. 


\section{References}

Adger, W. N., Arnell, N., \& Tompkins, E. (2005). Successful adaptation to climate change across scales. Global Environmental Change, 15(2), 77-86. doi:10.1016/j.gloenvcha.2004.12.005

Adger, W. N., Dessai, S., Goulden, M., Hulme, M., Lorenzoni, I., Nelson, D. R., ... Wreford, A. (2009). Are there social limits to adaptation to climate change? Climatic Change, 93(3-4), 335-354. doi:10.1007/s10584-008-9520-z

Adger, W. N., Eakin, H., \& Winkels, A. (2009). Nested and teleconnected vulnerabilities to environmental change. Frontiers in Ecology and the Environment, 7(3), 150-157. doi:10.1890/070148

Alkire, S. (2002). Dimensions of Human Development. World Development, 30(2), 181205.

Anderson, E. R., Flores, E. A., Perez, A. L., Carrillo, R. J. B., \& Sempris, E. (2008). Potential Impacts of Climate Change on Biodiversity in Central America, Mexico, and the Dominican Republic (p. 104). Panama City, PA.

Arriagada, R. a., Sills, E. O., Pattanayak, S. K., Cubbage, F. W., \& González, E. (2010). Modeling fertilizer externalities around Palo Verde National Park, Costa Rica. Agricultural Economics, 41(6), 567-575. doi:10.1111/j.1574-0862.2010.00472.x

Barten, F., Montiel, R. P., Espinoza, E., \& Morales, C. (2002). Democratic governance fairytale or real perspective? Lessons from Central America. Environment and Urbanization, 14(1), 129-144. doi:10.1177/095624780201400111

Below, T. B., Mutabazi, K. D., Kirschke, D., Franke, C., Sieber, S., Siebert, R., \& Tscherning, K. (2012). Can farmers' adaptation to climate change be explained by socio-economic household-level variables? Global Environmental Change, 22(1), 223-235. doi:10.1016/j.gloenvcha.2011.11.012

Christoplos, I. (2010). The Multiplicity of Climate and Rural Risk (No. 2010:08) (pp. 142). Copenhagen.

CIFOR. (2014). Tropical Dry Forests, Under Threat \& Under-Researched (p. 4). Bogor, Indonesia. Retrieved from http://www.cifor.org/publications/pdf_files/WPapers/DPBlackie1401.pdf

Cohen, S., Demeritt, D., Robinson, J., \& Rothman, D. (1998). Climate change and sustainable development: towards dialogue. Global Environmental Change, 8(4), 341-371. doi:10.1016/S0959-3780(98)00017-X 
CONARROZ. (2012). INFORME ESTADISTICO PERIODO 2011/2012 (p. 65). San José, CR.

Dow, K., Berkhout, F., \& Preston, B. L. (2013). Limits to adaptation to climate change: a risk approach. Current Opinion in Environmental Sustainability, 5(3-4), 384-391. doi:10.1016/j.cosust.2013.07.005

Dow, K., Berkhout, F., Preston, B. L., Klein, R. J. T., Midgley, G., \& Shaw, M. R. (2013). Limits to adaptation. Nature Climate Change, 3(April), 305-307.

Eakin, H. (2003). The Social Vulnerability of Irrigated Vegetable Farming Households in Central Puebla. The Journal of Environment \& Development, 12(4), 414-429. doi:10.1177/1070496503257733

Eakin, H. (2005). Institutional change, climate risk, and rural vulnerability: Cases from Central Mexico. World Development, 33(11), 1923-1938. doi:10.1016/j.worlddev.2005.06.005

Eakin, H. (2006). Weathering Risk in Rural Mexico: Climatic, Institutional, and Economic Change (1st ed., p. 288). Tucson, AZ: The University of Arizona Press.

Eakin, H., Winkels, A., \& Sendzimir, J. (2009). Nested vulnerability: exploring crossscale linkages and vulnerability teleconnections in Mexican and Vietnamese coffee systems. Environmental Science \& Policy, 12(4), 398-412. doi:10.1016/j.envsci.2008.09.003

Edelman, M. (1992). The Logic of the Latifundio: The Large Estates of Northwestern Costa Rica Since the Late Nineteenth Century (1st ed., p. 478). Stanford, CA: Stanford University Press.

Edelman, M. (1999). Peasants Against Globalization: Rural Social Movements in Costa Rica (1st ed., pp. 1-308). Stanford, CA: Stanford University Press.

Eriksen, S., Aldunce, P., Bahinipati, C. S., Martins, R. D., Molefe, J. I., Nhemachena, C., ... Ulsrud, K. (2011). When not every response to climate change is a good one: Identifying principles for sustainable adaptation. Climate and Development, 3(1), $7-$ 20. doi:10.3763/cdev.2010.0060

Eriksen, S. H., \& O’Brien, K. (2007). Vulnerability, poverty and the need for sustainable adaptation measures. Climate Policy, 7(4), 337-352. doi:10.3763/cpol.2007.0717

Eriksen, S., \& Silva, J. a. (2009). The vulnerability context of a savanna area in Mozambique: household drought coping strategies and responses to economic change. Environmental Science \& Policy, 12(1), 33-52. doi:10.1016/j.envsci.2008.10.007 
Füssel, H.-M. (2007). Adaptation planning for climate change: concepts, assessment approaches, and key lessons. Sustainability Science, 2(2), 265-275. doi:10.1007/s11625-007-0032-y

Heller, J. (1961). Catch-22 (1st ed.). Simon \& Schuster.

Hidalgo, C. (2014). Growth without Poverty Reduction: The Case of Costa Rica. Cato Institute - Economic Development Bulletin, (18).

Honey, M. (1994). Hostile Acts: US Policy in Costa Rica in the 1980s (1st ed., p. 323). Miami: University Press of Florida. International.

Intergovernmental Panel on Climate Change (IPCC). (2001). Climate Change 2001: Impacts, Adaptation and Vulnerability. Summary for Policy Makers (pp. 1-56). Geneva, SZ.

Jiménez R., J. A., González J., E., \& Mateo-Vega, J. (2001). Perspectives for the Integrated Management of The Tempisque River Basin (1st ed., p. 33). San José, CR: Organization for Tropical Studies.

Jones, R. N. (2001). An Environmental Risk Assessment/ Management Framework for Climate Change Impact Assessments. Natural Hazards, 23, 197-230.

Karmalkar, a. V., Bradley, R. S., \& Diaz, H. F. (2008). Climate change scenario for Costa Rican montane forests. Geophysical Research Letters, 35(11), L11702. doi:10.1029/2008GL033940

Klein, R. J. T., Eriksen, S. E. H., Næss, L. O., Hammill, A., Tanner, T. M., Robledo, C., \& O'Brien, K. L. (2007). Portfolio screening to support the mainstreaming of adaptation to climate change into development assistance. Climatic Change, 84(1), 23-44. doi:10.1007/s10584-007-9268-x

Kuzdas, C., Wiek, A., Warner, B., Vignola, R., \& Morataya, R. (2014). Analysis of water governance in rural Costa Rica: Implications for water policy and sustainability in the dry tropics. Environmental Management, 1-18.

Leichenko, R. M., Brien, K. L. O., \& Solecki, W. D. (2010). Climate Change and the Global Financial Crisis: A Case of Double Exposure. Annals of the Association of American Geographers, 100(November 2009), 963-972.

Leichenko, R., \& O’Brien, K. (2008). Environmental Change and Globalization: Double Exposures (1st ed., p. 192). Oxford: Oxford University Press.

Lerner, a., Sweeney, S., \& Eakin, H. (2013). Growing buildings in corn fields: Urban expansion and the persistence of maize in the Toluca Metropolitan Area, Mexico. Urban Studies. doi:10.1177/0042098013506064 
Marois, T. (2005). From Economic Crisis to a "State" of Crisis?: The Emergence of Neoliberalism in Costa Rica. Historical Materialism, 13(3), 101-134. doi:10.1163/1569206054927671

Marshall, N. A., \& Marshall, P. A. (2007). Conceptualizing and Operationalizing Social Resilience within Commercial Fisheries in Northern Australia. Ecology And Society, 12(1).

Martin, R., Müller, B., Linstädter, A., \& Frank, K. (2013). How much climate change can pastoral livelihoods tolerate? Modelling rangeland use and evaluating risk. Global Environmental Change. doi:10.1016/j.gloenvcha.2013.09.009

Max-Neef, M. (1993). Human scale development: Conception, application, and further reflections. London: Apex Press.

McDowell, J. Z., \& Hess, J. J. (2012). Accessing adaptation: Multiple stressors on livelihoods in the Bolivian highlands under a changing climate. Global Environmental Change, 22(2), 342-352. doi:10.1016/j.gloenvcha.2011.11.002

Monge-González, R., Rivera, L., \& Rosales-Tijerino, J. (2010). Productive Development Policies in Costa Rica: Market Failures, Government Failures, and Policy Outcomes (p. 89). IDB working paper series; 157.

Moor, G. (1998). ECONOMIES OF SCALE IN CONTRACT HARVESTING OF SUGARCANE. Proc S Afr Sug Technol Assessment, 72(1), 55-57.

Morton, J. F. (2007). The impact of climate change on smallholder and subsistence agriculture. Proceedings of the National Academy of Sciences of the United States of America, 104(50), 19680-5. doi:10.1073/pnas.0701855104

Neil Adger, W. (1999). Social Vulnerability to Climate Change and Extremes in Coastal Vietnam. World Development, 27(2), 249-269. doi:10.1016/S0305-750X(98)001363

O’Brien, K. L., \& Leichenko, R. M. (2000). Double exposure: assessing the impacts of climate change within the context of economic globalization. Global Environmental Change, 10(3), 221-232. doi:10.1016/S0959-3780(00)00021-2

O’Brien, K., Quinlan, T., \& Ziervogel, G. (2009). Vulnerability interventions in the context of multiple stressors: lessons from the Southern Africa Vulnerability Initiative (SAVI). Environmental Science \& Policy, 12(1), 23-32. doi:10.1016/j.envsci.2008.10.008

Roncoli, C., Ingram, K., \& Kirshen, P. (2001). The costs and risks of coping with drought: livelihood impacts and farmers' responses in Burkina Faso. Climate Research, 19(2), 119-132. 
Sandelowski, M. (2000). Focus on Research Methods Whatever Happened to Qualitative Description ?, 334-340.

Smit, B., \& Wandel, J. (2006). Adaptation, adaptive capacity and vulnerability. Global Environmental Change, 16(3), 282-292. doi:10.1016/j.gloenvcha.2006.03.008

TABOGA. (2014). Taboga Ingenio Logistics Processes. Logistics Processes. Retrieved December 04, 2014, from http://www.taboga.co.cr/index.php?option=com_content $\&$ view=article $\&$ id $=12 \&$ Ite mid=11\&lang=en

Torres, C. A. (1997). Small farmers and the transition to non-traditional agriculture in Guanacaste, Costa Rica. MASSACHUSETTS INSTITUTE OF TECHNOLOGY.

Turner, B. L., Kasperson, R. E., Matson, P. a, McCarthy, J. J., Corell, R. W., Christensen, L., ... Schiller, A. (2003). A framework for vulnerability analysis in sustainability science. Proceedings of the National Academy of Sciences of the United States of America, 100(14), 8074-9. doi:10.1073/pnas.1231335100

Warner, B. P., Kuzdas, C., \& Childers, D. L. (2015). Political economic barriers to climate change adaptations: A study of agrarian rural development in Northwest Costa Rica. Journal of Agrarian Change.

Yohe, G., \& Tol, R. S. J. (2002). Indicators for social and economic coping capacity moving toward a working definition of adaptive capacity. Global Environmental Change, 12, 25-40.

Yohe, G. W., Lasco, R. D., Ahmad, Q. K., Arnell, N. W., Cohen, S. J., Hope, C., ... Perez, R. T. (2007). Perspectives on climate change and sustainability. In M. L. Parry, O. F. Canziani, J. P. Palutikof, P. J. van der Linden, \& C. E. Hanson (Eds.), Climate Change 2007: Impacts, Adaptation and Vulnerability. Contribution of Working Group II to the Fourth Assessment Report of the Intergovernmental Panel on Climate Change (1st ed., pp. 811-841). Cambridge, UK: Cambridge University Press. 